

International Journal of Academic Research in Accounting, Finance and Management Sciences

Vol. 8, No.4, October 2018, pp. 39-51

E-ISSN: 2225-8329, P-ISSN: 2308-0337

(c) 2018 HRMARS

www.hrmars.com

To cite this article: Masengeli O.G.W., Kiragu, D.N., Kamau, R. (2018). Effect of Financial Misstatement and Corruption on Fraud Risk among State Corporations in Mombasa County in Kenya, International Journal of Academic Research in Accounting, Finance and Management Sciences 8 (4): 39-51.

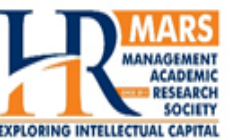

http://dx.doi.org/10.6007/IJARAFMS/v8-i4/5184 (DOI: 10.6007/IJARAFMS/v8-i4/5184)

\title{
Effect of Financial Misstatement and Corruption on Fraud Risk among State Corporations in Mombasa County in Kenya
}

\author{
Gilbert Masengeli O.G.W. ${ }^{1}$, David N. KIRAGU ${ }^{2}$, Riro KAMAU ${ }^{3}$ \\ ${ }^{1}$ Master of Science in Forensics and Security Management, ${ }^{1}$ Email: gmasengeli95@gmail.com \\ ${ }^{2,3}$ School of Business Management and Economics, Dedan Kimathi University of Technology, Kenya, \\ ${ }^{2}$ Email:drkiragu@gmail.com, ${ }^{3}$ E-mail: rirogk@gmail.com
}

\begin{abstract}
The aim of this study was to evaluate effect of financial misstatement and corruption on fraud risk among state corporations in Mombasa County in Kenya. The study was anchored the fraud triangle theory. The study used a descriptive research design since it reports and determines things as they are. The sample size of the study consisted of 64 internal auditors and accountants of state corporations in Mombasa County. Since the accessible population is regarded as small no sampling will be done and therefore a census survey was used. This means all the internal auditors of state corporations was used. Structured questionnaires were used for data collection. The questionnaire will be self-administered. The study used a Statistical Package for Social Sciences (SPSS) for both descriptive analyses, that is, mean, percentages, and correlations. For inferential analysis, a both bivariate linear and multiple linear regressions was carried out. Inferential statistics was carried out at 95\% degree of confidence. Results were presented in Tables and Figures. The study concluded that financial misstatement had a positive and significant effect fraud risk among state corporations in Mombasa County. To reduce financial misstatement reporting, the study recommends the management of state corporations in Mombasa County to adopt more robust monitoring measures to avoid manipulation of their financial records. There is also need for the management of state corporations to emphasize on proper disclosure of financial statement information. The study also recommends the management of state corporations to ensure that their expenditures are not overstated through the provision of accountability reports. The study further recommends for the adoption of policies to handle financial statements such as Forensic accounting and auditing.
\end{abstract}

Key words

Financial Statement, Corruption, Fraud Risk, State Corporations

Received: 3 Dec $2018 \quad$ C The Authors 2018

Revised: 18 Dec 2018 Published by Human Resource Management Academic Research Society (www.hrmars.com)

Accepted: 28 Dec 2018 This article is published under the Creative Commons Attribution (CC BY 4.0) license. Anyone may Published Online: 4 lan 2019 reproduce, distribute, translate and create derivative works of this article (for both commercial and noncommercial purposes), subject to full attribution to the original publication and authors. The full terms of this license may be seen at: http://creativecommons.org/licences/by/4.0/legalcode

\section{Introduction}

\subsection{Background of the Study}

Financial fraud refers to the intentional act to gain monetary advantage unfairly and unlawfully. It relates to activities that encourage fraudulent financial reporting such as misappropriation of assets (inside or outside the system, such as: embezzlement, payroll fraud and theft), (ACFE, 2014). According to Rubin (2015) financial fraud also include illegal or unethical sales practices and commercial and public bribery. Organizations across of the global continue to be affected by the effects of financial fraud (Granter, 2014). State corporations being state owned enterprises that are managed and run by the government have always been viewed as a public venture by many as they have a wide global customer base, high 
profitability margins and customer retention. Nevertheless, just like other businesses they are also faced with numerous challenges including financial fraud that have in the long-run affected their performance, (Soltani, 2013). Issues ranging from acquiring counterfeit goods, identity fraud, embezzlement, internal theft to payoffs others have affected the performance of these organizations.

According to the Financial Fraud Action UK (2015), fraud losses statistics in state corporations across the county was a still a major threat to the total revenues from the state companies. The state organs have been facing several types of financial including; embezzlement of funds and internal theft. In this case, the UK fraud losses totaled to 479 million pounds. This promoted FFA UK to lead the collective light against fraud in the UK. In the U.S.A according to the Report of the USA National Commission on Fraudster Financial Reporting in the majority of the studied cases, state agencies management, such as chief executive, president and chief financial officer, were the fraudulent perpetrators. In some cases, it was found that there were made intentional false disclosures from the accountant throughout falsified documents and records (NCFFR, 2015). On the other hand in Australia almost half of the state corporations suffered some form of financial fraud. In this case financial fraud had cost the Australian government $\$ 5.8$ billion in 2015 (Hooper, 2016).

In South Africa, financial fraud costs government trillions of Rands thus damaging the national reputation and government entities are among the most common victims. Government entities are victims of every conceivable kind of swindle, and everyone pays for these frauds in direct and indirect ways. This prompted a policy to be formulated to regulate these cases. This policy framework works to control fraudulent activities in the county (Nkune, 2013). On the hand, in Ghana Kwame (2014) asserts that financial fraud is till common in state corporations in Ghana. Although it occurs least in only $10 \%$ of all the fraud cases, it is easily the most expensive in terms of value lost. Kwame notes that financial fraud centers on the manipulation of financial statements in order to create financial opportunities for several individuals. Fraudulent activities in this case include; manipulation of stock price and increased year-end bonuses.

In East Africa, According to KPMG (2012), Burundi, Uganda, Kenya and Tanzania make up 74\% of all the financial fraud cases in the East African region with Kenya standing out with $23 \%$ of the reported cases, Burundi at $21 \%$, Uganda at $18 \%$ and Tanzania at $12 \%$. Most fraud in East Africa target governments and financial sectors with misappropriation of funds, bribery and corruption extremely high in the organizations in these countries.

In Kenya, although there are effective policies, systems of checks and balances and physical security, fraud most financial fraud cases in state corporations are in form of misappropriation or embezzlement of funds, bribery and corruption and financial statement frauds (Wanyama, 2009). In is therefore no surprise that the economic survey of 2010 by PwC found that financial fraud incidents and cases in state corporations had increased with higher margins in the year 2010 than in any other preceding year. To this end, approximately, $90 \%$ of the respondents to the study indicated that most state entities had recorded serious cases of fraud. These cases of financial fraud have been increasing affecting the performance of state corporations thus leading to low profitability, (PwC, 2010).

State corporations in Mombasa County specifically have been on the radar for cases of financial fraud considering that the county acts as the gateway to East Africa. Issues ranging from bribery, tax aversion, financial statement fraud, misappropriation of funds and forgery are still dominant is these organizations (EACC, 2016). That is why this study will focus on the effects of financial fraud on performance of state corporations in the county.

\subsection{Statement of the Problem}

State corporations in Kenya have been experiencing financial fraudulent activities that have been affecting their performance. This has seen some of these companies register poor productivity thus face a threat of closure with the management of these companies featuring as the poorest and their internal controls extremely vulnerable to prevent financial fraud. Some organizations in Kenya have collapsed due to financial fraud. Kenya lost 1.4 billion shillings as a result of fraudulent activities in state corporations. This is attributed to the failure of statutory auditing to prevent and reduce financial fraud.

According to the 2010 economic crime survey carried out by PwC, cases of fraud have risen sharply compared to preceding years affecting all sectors of the Kenyan economy. Globally, an average 
organization is estimated to lose $5 \%$ of its revenue each year due to significant frauds which also include financial statement fraud. If this rate of loss is applied to 2011 Gross World Product, this causes an anticipated fraud loss of $\$ 3.5$ trillion. The impact is that financial statement fraud cases have resulted in financial losses, a loss of shareholder value and bankruptcies (Center for Audit Quality, 2010). Internal risk management systems are losing ground to highly-networked, sophisticated fraudsters.

Poor performance of most state corporations in Kenya is caused by misappropriation of funds by management or sub-ordinate employees in the organizations. In May 2016, the government put on notice several state corporations among which included sugar companies in western Kenya such as Mumias Sugar Company for massive misappropriation of funds. It is worth stating that corruption and misappropriation of funds in the organizations has often been blamed for such woes. An example is in the sugar industry where majority of the sugar companies had to change their top administrations since misappropriation of funds had contributed to their dismal performance and occupational strikes. For instance in April 2017, the government had to change the management of Chemelil Sugar Company (one of Kenya top sugar company) due to poor productivity coupled with misappropriation of funds. It is because of such cases that this study seeks to investigate the drivers of fraud risk among state corporations in Kenya.

There are also knowledge gaps in the previous studies that have focused on fraud risks. Previous studies for instance, Mustafa and Youssef (2010) investigated the relationship between the financial expertise of the audit committee and the incidence of asset misappropriation in publicly held companies, Majid et al. (2010) focused on the opinions of local authority employees on the issue of asset misappropriation in Malaysia, Akindele (2011) looked at the effect of fraud as a negative catalyst in the Nigerian Banking Industry, Gikiri (2012) sought to determine the influence of fraud risk management practices in commercial banks and their effect on fraud risk exposure while Odhiambo (2013) looked at the effects of financial fraud and liquidity on financial performance of commercial banks in Kenya. These studies focused on fraud risks in commercial banks in Kenya thereby presenting a contextual gap, this study will fill this gap by looking at the drivers of fraud risk in state corporations in Mombasa County.

Additionally, Maxwell et al (2012) assessed the effect of corruption in humanitarian assistance through in humanitarian agencies only focused on only one driver of fraud risk; this gap was filled by focusing on financial misstatement, asset misappropriation and corruption. The studies also reveal differences in the contexts ranging from developed countries such as USA to developing countries such as Nigeria. This contextual knowledge gap can be filled by focusing on the drivers of fraud risk among state corporations in Kenya.

\subsection{Research Objective}

i. To assess the effects of financial misstatement on fraud risk among state corporations in Mombasa County

ii. To explore the influence of corruption on fraud risk among state corporations in Mombasa County.

\section{Theoretical Review}

\subsection{The Fraud Triangle Theory}

The proponent of fraud triangle theory was Donald Cressey in 1950. Being a criminologist, Cressey did a study of fraud by asserting that people do things with some reasons. He interviewed 250 criminals in 5 months putting into consideration that; the individual being interviewed must be a person of trust in good faith and must have violated the trust. In this case his findings were that there are three major factors that are present for a person to violate this trust (Cressey 1953). In this case the three factors were causes by; non-shareable financial problem, opportunity to commit the trust violation, and rationalization by the trust violator. As far as non-shareable financial problem, is concerned, Cressey posited that persons become trust violators when they conceive of themselves as having incurred financial obligations which are considered as non-socially sanction-able and which, consequently, must be satisfied by a private or secret means. Moreover, Cressey argues that perpetrator of fraud must formulate some type of morally acceptable rationalization before engaging in unethical behavior. Rationalization refers to the justification that the unethical behavior is something other than criminal activity. If an individual cannot justify unethical actions, it is unlikely that he or she will engage in fraud. It is important to note that rationalization 
is difficult to observe, as it is impossible to read the perpetrator's mind (Cressey 1953 in Wells, 2005). Individuals who commit fraud possess a mind-set that allows them to justify or excuse their fraudulent actions (Hooper and Pornelli, 2010). Rationalization is a justification of fraudulent behavior because of an employee's lack of personal integrity, or other moral reasoning (Rae and Subramanian, 2008). Some individuals are more prone than others to commit fraud. That the propensity to commit fraud depends on people ethical values as well as on their personal circumstances such as job insecurity due to downsizing, redundancy, a work environment that inspires resentment such as being, passed over for promotion. Therefore this theory can be used to understand personal and corporate pressures which motivate proxies for fraud commitment.

\subsection{Empirical Review}

Odhiambo (2013) did a study on the effects of financial fraud and liquidity on financial performance of commercial banks in Kenya. The objective of the study was to evaluate the effects of financial fraud and liquidity on the financial performance of commercial banks in Kenya. The study adopted a descriptive research design. Regression analysis model was used to analysis the data. The study found out that financial fraud loss and liquidity ratios had a strong and significant influence on financial performance of commercial banks in Kenya. Another study by Makori (2016) sought to assess the influence of internal control systems on fraud risk management among banks in Kisii town. The study focused on 15 banks in Kisii town. The sample size comprised of 130 respondents. The results of the study showed that internal control systems influence fraud risk management; positively and significantly.

Gikiri (2012) did a study to determine the influence of fraud risk management practices in commercial banks and their effect on fraud risk exposure. The main objective was to find the combined effect of fraud risk management practice, fraud prevention and fraud detection on fraud risk incidence in commercial banks in Kenya. The results of the study showed that Kenyan commercial banks were applying several fraud risk detection methods and prevention methods to control existing fraud risks. The study revealed that information sharing on fraud was key to reducing fraud risks.

Akindele (2011) in his study of fraud as a negative catalyst in the Nigerian Banking Industry, found out that lack of training, communication gap and leadership skills were the greatest causes of fraud in Banks. He advised that adequate internal control mechanism be put in place and that workers satisfaction and comfort be taken care of. Similarly, Abiola and Oyewole (2013) evaluated the effects of financial statements on fraud detection in selected Nigerian commercial banks and showed a statistically significant positive relationship between risk assessment and fraud detection. Similarly, Akinyomi (2010) in a study on the effect of financial statements on Nigerian banks found that there was a strong positive relationship between risk assessment and fraud management while studying fraud in Nigerian banks. Maxwell et al (2012) sought to assess the effect of corruption in humanitarian assistance through humanitarian agencies. The study employed descriptive survey research design. The unit of analysis was humanitarian agencies. Results of the study revealed that accurate targeting of those who need assistance poses significant corruption risk.

Graycar et al. (2012) also looked at past corruption cases to identify opportunity and control structure in order to devise preventive mechanism. The study used multiple cases analysis. The study concluded that deficiency in control structure positively and significantly influences the existing opportunities for corruption thereby developing systematic methods. Thanos and Petrou (2014) in concurrence, attest that corruption acts as a "helping hand" to commerce. Evidence from bank records show that bribing mechanisms had helped facilitate transactions and enable private agents to pursue economic activities they could not pursue otherwise.

\subsection{Conceptual Framework}

A conceptual framework is that logically, developed, described and elaborated network of interrelationships among variables which are deemed to be integrated as part of the dynamics to be investigated. According to Seraken (2003), it states the researcher's ideological stand from his or her agreement or disagreement with the issues at hand. A conceptual framework has to have both 
independent and dependent variables. In this case the independent variable was financial statement fraud while the dependent variable was fraud risk in state corporations in Mombasa County.

Financial Report Misstatements
- Extent of mmanipulation of financial
records
- No. of improper disclosures noted
no. of overstatements in expenditure
noted

\section{Corruption}

- No, of illegal gratuities paid

- Extents of Bribery cases

- Conflict of interest cases

Independent variables

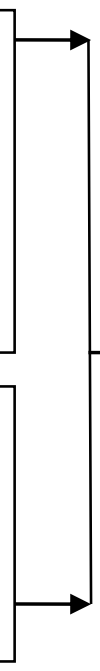

$\longrightarrow$\begin{tabular}{ll|}
\hline & Fraud risks \\
$\bullet$ & Frequency of frauds \\
$\bullet$ & Amount of frauds \\
& \\
\hline
\end{tabular}

Dependent variable

Figure 1. Conceptual framework

\section{Methodology of research}

This study adopted a descriptive research design. A descriptive research design was adopted because it allows for close examination of data, determination and reporting of information within a specific context. The sampling frame of the current study comprised of a list of 32 internal auditors and 32 accountants of state corporations in Mombasa County. The list was obtained from Kenya national treasury for all state corporations situated in the county. The study focused on state corporations in Mombasa County to determine the causes of high fraud cases reported in the County. The target population for this study consisted of all 32 internal auditors and accountants working in the 32 state corporations in Mombasa County. The unit of analysis for the study was the state corporations in Mombasa County. The unit of observation was internal auditors and accountants. The population of this study was regarded as a small population and there was therefore no need to do sampling and therefore all the 64 officers comprising of internal auditors and accountants of state corporations were subject of this study. The study collected primary data using a semi structured questionnaire captured using a 5-point Likert scale. Questionnaires were dropped and picked later to enable the respondents have enough time to respond to the questionnaires. The data was collected after a successful pilot study. The validity and reliability of the questionnaires was established through expert examination and Cronbach Alpha tests respectfully. The pilot test achieved Cronbach alpha coefficient of 0.776 which is reliable according to Cronbach (1951).

Descriptive and inferential statistics was used to analyze the primary data. The analyzed data was presented in form of tables and charts. Inferential statistics on the other hand includes correlation and regression analysis. A multiple linear regression model was used to ascertain the relationship between the study variables, that is, drivers of fraud risk. Because of the presence of more than one predictor variable, a multiple linear regression analysis was suitable. The model is as indicated: $Y=\beta_{0}+\beta_{1} X_{1}+\beta_{2} X_{2}+\varepsilon$ Where; $Y=$ Fraud Risk, $X_{1}=$ Financial Report Misstatements, $X_{2}=$ Corruption, $\beta_{0}=$ Represents the constant term, $\beta_{1}$ and $\beta_{2}=$ Predictor variables coefficients, $\varepsilon=$ the error term. The study conducted ANOVA test to establish the model significance. In this study, the level of significance was at $5 \%$ which implies that all statistical tests were done at $95 \%$ level of significance.

\subsection{Findings and Discussions}

The findings on response rate of the study showed that a total of 64 of questionnaires were administered. A total of 54 questionnaires were filled and returned. This represented an overall successful response rate of $84.38 \%$. This confirms an argument by Kothari (2004) that a response rate of $50 \%$ or more is adequate for a descriptive study. 


\section{Distribution of Demographic Information}

The results in Table 1 below showed that of the $20.4 \%$ of the respondents were aged below 30 years; those who were aged between 31 to 40 years and those between 41 and 50 years were both $24.1 \%$. Finally, the results of the study revealed that those who were aged above 50 years were $31.5 \%$. The results of the study imply that the majority of the staff working in state corporations was aged above 30 years. The findings on the level of education indicated that $37 \%$ of the respondents had diplomas, $31.5 \%$ have bachelor's degree, those that have master's degree were $16.7 \%$ while those that have PhD degree level education were $14.8 \%$. The findings reveal that majority of the respondents are literate. This indicates that with literacy, interpretation of the questions was easy and it contributed to the high reliability. Regarding the effects of financial fraud on the performance of state corporations, findings of the study revealed that majority $35.2 \%$ of the respondents indicated that financial fraud leads to a sharp decrease in the organizational performance, those that indicate that it leads to a decrease were $33.3 \%$ while those who indicated moderate were $13 \%$ and about $18.5 \%$ of the respondents indicated that they did not observe any effect of fraud on the organizational performance.

Table 1. Demographic Analysis Results

\begin{tabular}{llc}
\hline & \multicolumn{1}{c}{ Category } & Results \\
\hline Age Of Respondents & Below 30 Years & $20.4 \%$ \\
& Between 31 And 40 Years & $24.1 \%$ \\
& Between 41 and 50 years & $24.1 \%$ \\
& Over 50 Years & $26.9 \%$ \\
\hline Level of Education & Diploma & $37 \%$ \\
& Bachelors Degree & $31.5 \%$ \\
& Masters Degree & $16.7 \%$ \\
& PhD Degree & $14.8 \%$ \\
\hline Effects of Financial Fraud on the Performance of State Corporations & Sharp Decrease & $35.2 \%$ \\
& Moderate Decrease & $13 \%$ \\
& Decrease & $33.3 \%$ \\
& No Observed Effect & $18.5 \%$ \\
\hline
\end{tabular}

\section{Fraud Risk}

The study sought to determine the extent to which the respondents agree or disagree with the statements regarding frauds risks in their corporation within Mombasa County. The findings showed that 49.2\% of the respondents indicated that they strongly agree that Fraud incidences are frequent in our corporation, those who indicated agree were $37.8 \%$ while only $13 \%$ of them neither agreed nor disagreed with the statement. The results of the study also revealed that $32.2 \%$ of the respondents indicated that they strongly that the number of reported fraud cases in their organization has been increasing while the majority of them indicated agree and only $2.3 \%$ of them neither agreed nor disagreed. Finally, the results of the study showed that majority of the respondents strongly agreed with the statement that the amount of revenue lost in terms of fraud has been on the rise, those who indicated agree were $17.9 \%$ while only $5.8 \%$ of them neither agreed nor disagreed.

Table 2. Descriptive Analysis Results for Fraud Risk

\begin{tabular}{lccccc}
\hline \multicolumn{1}{c}{ Statement } & $\begin{array}{c}\text { Neutral } \\
(\%)\end{array}$ & $\begin{array}{c}\text { Agree } \\
(\%)\end{array}$ & $\begin{array}{c}\text { Strongly } \\
\text { Agree (\%) }\end{array}$ & Mean & SD \\
\hline $\begin{array}{l}\text { Fraud incidences are frequent in our corporation } \\
\begin{array}{l}\text { Number of reported fraud cases in our organization } \\
\text { has been increasing }\end{array}\end{array}$ & 13 & 37.8 & 49.2 & 4.06 & 1.04 \\
$\begin{array}{l}\text { The amount of revenue lost in terms of fraud has } \\
\text { been on the rise }\end{array}$ & 2.3 & 65.5 & 32.2 & 4.11 & 0.87 \\
$\quad$ Average & 5.8 & 17.9 & 76.3 & 4.37 & 0.64 \\
\hline
\end{tabular}




\subsection{Diagnostic Test Results}

Normality Tests Results

The Gaussian test results are presented in table 3. The table shows that normality test statistics computed for fraud risk using both Kolmogorov-Smirnov (K-S) and Shapiro-Wilk tests are significant with $p$ value of .200 and .881 respectively. The results revealed that $p$-values are greater than 0.05 and thus null hypothesis $\left(\mathrm{H}_{0}\right)$ is accepted implying the data are normally distributed.

Table 3. Test for Normality for Study Variables

\begin{tabular}{lcccccc}
\hline & \multicolumn{2}{c}{ Kolmogorov-Smirnova } & \multicolumn{2}{c}{ Shapiro-Wilk } \\
& Statistic & df & Sig. & Statistic & df & Sig. \\
\hline Fraud Risk & 0.259 & 54 & $.200^{*}$ & 0.792 & 54 & .881 \\
\hline a Lilliefors Significance Correction & & & & & & \\
\hline
\end{tabular}

*. This a lower bound of the true significance

\section{Test for Multicollinearity}

Normally if the association between the independent variables has a value of more 0.8 , then multicollinearity is said to be present. This study used a variance inflation factor (VIF) method to test for Multicollinearity of the study variables. The results indicated in Table 4 showed that there was no presence of Multicollinearity since all the values of VIF were below 10.

Table 4. Test of Multicollinearity Results

\begin{tabular}{lcc}
\hline \multicolumn{1}{c}{ Variable } & Tolerance & VIF \\
\hline Financial Misstatement & 0.996 & 1.004 \\
Corruption & 0.994 & 1.006 \\
\hline
\end{tabular}

Test of Independence Results

The study used Durbin-Watson test to establish the presence of Autocorrelation. A value of 2 indicates the absence of autocorrelation, a value less than 2 indicates a positive autocorrelation while a value greater than 2 reveals presence of negative autocorrelation. The findings in Table 5 revealed the presence of a positive autocorrelation. A rule of thumb is that test statistic values in the range of 1.5 to 2.5 are relatively normal. Values outside of this range could be cause for concern. Field (2009) suggests that values under 1 or more than 3 are a definite cause for concern.

Table 5. Results for Tests for Independence

\begin{tabular}{llc}
\hline \multicolumn{1}{c}{ Variable } & Test & Statistic \\
\hline Financial Misstatement & Durbin Watson & 1.921 \\
Corruption & Durbin Watson & 1.837 \\
Fraud Risk & Durbin Watson & 1.843 \\
\hline
\end{tabular}

Financial Misstatement and Fraud Risk

The study sought to assess the effects of financial misstatement on fraud risk among state corporations in Mombasa County. Results of the study showed that $38.9 \%$ of the respondents strongly agreed that the organization has cases of manipulation of financial records, those who indicated agree were also $38.9 \%$ while those who neither agreed nor disagree were $14.8 \%$ and only $7.4 \%$ of them indicated disagree. The results also revealed that majority $81.5 \%$ of the respondents strongly agreed with the statement that there is improper disclosure of financial statement information in the organization while $18.5 \%$ of them neither agreed nor disagreed. Moreover, findings showed that majority $85.2 \%$ of the respondents strongly agreed that their organization has cases of overstating of expenditure while providing accountability reports while $14.8 \%$ of them indicated agree. Furthermore, the study revealed that $14.8 \%$ of the respondents strongly agreed that there is an organizational policy on how to handle financial statements, $25.9 \%$ indicated agree, those who neither agreed nor disagreed were the majority $40.7 \%$ while those who disagreed were only $7.4 \%$ and $11.1 \%$ of the respondents strongly disagreed. Finally, results 
revealed that $11.1 \%$ of the respondents strongly agreed with the statement that Forensic accounting and auditing is often done to establish if there are cases of financial fraud, $33.3 \%$ of them indicated agree, $22.2 \%$ of them neither agreed nor disagreed while those who indicated disagree were $18.5 \%$ and $14.8 \%$ of the respondents strongly disagreed with the statement. These results imply that majority of the respondents agreed with the statements on financial misstatement as indicated by a mean of 3.98. The responses given by the respondents had a small variation as shown by a standard deviation of 0.89 . The results are consistent with the findings of a study by Odhiambo (2013) which found out that financial fraud loss and liquidity ratios had a strong and significant influence on financial performance of commercial banks in Kenya.

Table 7. Descriptive Analysis Results for Financial Misstatement

\begin{tabular}{|c|c|c|c|c|c|c|c|}
\hline Statements & SD (\%) & D (\%) & $\mathbf{N}(\%)$ & A (\%) & SA (\%) & Mean & SD \\
\hline $\begin{array}{l}\text { The organization has cases of manipulation } \\
\text { of financial records }\end{array}$ & 0.0 & 7.4 & 14.8 & 38.9 & 38.9 & 4.09 & 0.92 \\
\hline $\begin{array}{l}\text { There is improper disclosure of financial } \\
\text { statement information in the organization } \\
\text { The organization has cases of overstating }\end{array}$ & 0.0 & 0.0 & 18.5 & 0.0 & 81.5 & 4.63 & 0.78 \\
\hline $\begin{array}{l}\text { of expenditure while providing } \\
\text { accountability reports }\end{array}$ & 0.0 & 0.0 & 0.0 & 14.8 & 85.2 & 4.85 & 0.36 \\
\hline $\begin{array}{l}\text { There is an organizational policy on how to } \\
\text { handle financial statements }\end{array}$ & 11.1 & 7.4 & 40.7 & 25.9 & 14.8 & 3.26 & 1.15 \\
\hline $\begin{array}{l}\text { Forensic accounting and auditing is often } \\
\text { done to establish if there are cases of } \\
\text { financial fraud }\end{array}$ & 14.8 & 18. & 22.2 & 33.3 & 11.1 & 3.07 & 1.26 \\
\hline Average & & & & & & 3.98 & 0.89 \\
\hline
\end{tabular}

$\mathrm{SD}=$ Strongly Disagree $\mathrm{D}=$ Disagree $\mathrm{N}=$ Neutral $\mathrm{A}=$ Agree $\mathrm{SA}=$ Strongly Agree

The bivariate linear regression model linking Financial Misstatement and fraud risk shows that there is a relationship, $R=0.498$ and $R^{2}=0.248$ which mean that approximately $24.8 \%$ of the variation in fraud risk in state corporations in Kenya is due to a unit change in financial misstatement.

Table 8. Model Summary for Financial Misstatement

\begin{tabular}{ccccc}
\hline Model & R & R Square & Adjusted R Square & Std. Error of the Estimate \\
\hline 1 & .498 & 0.248 & 0.234 & 0.362 \\
\hline
\end{tabular}

a Predictors: (Constant), Financial Misstatement

The ANOVA regression results indicate that the linear relationship between Financial Misstatement and fraud risk has an $F$ value of $F=17.151$ which is significant with $p$ value $p=.0 .000<p=0.05$ meaning that the overall model is significant in predicting the effect of Financial Misstatement in state corporations in Kenya.

Table 9. Analysis of Variance for Financial Misstatement

\begin{tabular}{ccccccc}
\hline Model & & Sum of Squares & Df & Mean Square & F & Sig. \\
\hline 1 & Regression & 2.247 & 1 & 2.247 & 17.151 & .000 \\
& Residual & 6.814 & 52 & 0.131 & & \\
& Total & 9.061 & 53 & & & \\
\hline
\end{tabular}

a Dependent Variable: Fraud Risk

b Predictors: (Constant), Financial Misstatement

The regression coefficients for the model revealed that the beta coefficient of the resulting regression model, the constant $\beta_{0}=2.778$ is significant with $p$ value $p=0.000<p=0.05$. The coefficient $\beta=$ 0.403 , has a $p$ value, $p=.000$ which is less than $p=0.05$. This implies that financial misstatement as a driver of fraud risk is significant in the regression model. The study findings are consistent with the findings of a study by Akindele (2011) which found out that lack of training, communication gap and leadership skills were the greatest causes of fraud in Banks. Moreover, Abiola and Oyewole (2013) in agreement showed a 
statistically significant positive relationship between risk assessment and fraud detection. Similarly, Akinyomi (2010) in a study on the effect of financial statements on Nigerian banks found that there was a strong positive relationship between risk assessment and fraud management while studying fraud in Nigerian banks.

Table 10. Regression Coefficients for Financial Misstatement

\begin{tabular}{|c|c|c|c|c|c|c|}
\hline Model & Coefficients & B & Std. Error & Beta & $\mathbf{t}$ & Sig. \\
\hline \multirow[t]{2}{*}{1} & (Constant) & 2.778 & 0.39 & & 7.12 & 0.000 \\
\hline & Financial Misstatement & 0.403 & 0.097 & 0.498 & 4.141 & 0.000 \\
\hline
\end{tabular}

a Dependent Variable: Fraud Risk

\section{Corruption and Fraud Risk}

The study sought to explore the influence of corruption on fraud risk among state corporations in Mombasa County. The results of the study showed that $29.6 \%$ of the respondents strongly agreed that there are cases of bribery of employees by management to benefit them, $33.3 \%$ of them indicated agree, those who neither agreed nor disagreed were $13 \%$ while those who indicated disagree were $9.3 \%$ and $14.8 \%$ of them strongly disagreed. The results also revealed that $44.4 \%$ of the respondents strongly agreed that Bribery cases have affected the performance of this organization, those who indicated agree were $14.8 \%$ while those who neither agreed nor disagreed were $25.9 \%$ while $3.7 \%$ of them indicated disagree and $11.1 \%$ of the respondents indicated strongly disagree. Further, the findings of the study revealed that majority $55.6 \%$ of the respondents strongly agreed that the organization has policies to regulate cases of payoffs and kickbacks, $29.6 \%$ of them indicated agree, $7.4 \%$ of respondents failed to neither agree nor disagree while $7.4 \%$ of them also indicated disagree and those who strongly disagreed were $3.7 \%$. Moreover, the study revealed that $11.1 \%$ of the respondents strongly agreed that there are heavy penalties levied against perpetrators of payoffs and kickbacks, those who indicated agree were $55.6 \%$, those who neither agreed nor disagreed were $7.4 \%$ while those who disagreed were $14.8 \%$ and only $11.1 \%$ of them strongly disagreed. Finally, the findings of the study showed that $33.3 \%$ of the respondents strongly agreed that there are cases of bribery of employees by management to benefit them, $25.9 \%$ of them indicated agree, $11.1 \%$ of them neither agreed nor disagreed while only $22.2 \%$ and $7.4 \%$ of them strongly disagreed.

These results imply that most of the respondents agreed with the statements on corruption as indicated by a mean of 3.70. The results also showed that the responses given by the respondents were varied as indicated by a standard deviation of 1.28. The findings agree with the results of a study by Graycar et al. (2012) which concluded that deficiency in control structure positively and significantly influences the existing opportunities for corruption thereby developing systematic methods.

Table 11. Descriptive Results for Corruption

\begin{tabular}{lccccccc}
\hline \multicolumn{1}{c}{ Statements } & SD (\%) & $\mathbf{D ~ ( \% )}$ & $\mathbf{N}(\%)$ & $\mathbf{A ~ ( \% )}$ & SA (\%) & Mean & SD \\
\hline $\begin{array}{l}\text { There are cases of bribery of employees by } \\
\text { management to benefit them }\end{array}$ & 14.8 & 9.3 & 13.0 & 33.3 & 29.6 & 3.54 & 1.40 \\
$\begin{array}{l}\text { Bribery cases have affected the performance } \\
\text { of this organization }\end{array}$ & 11.1 & 3.7 & 25.9 & 14.8 & 44.4 & 3.78 & 1.36 \\
$\begin{array}{l}\text { The organization has policies to regulate cases } \\
\text { of payoffs and kickbacks }\end{array}$ & 3.7 & 7.4 & 7.4 & 25.9 & 55.6 & 4.22 & 1.11 \\
$\begin{array}{l}\text { There are heavy penalties levied against } \\
\text { perpetrators of payoffs and kickbacks }\end{array}$ & 11.1 & 14.8 & 7.4 & 55.6 & 11.1 & 3.41 & 1.21 \\
$\begin{array}{l}\text { There are cases of bribery of employees by } \\
\text { management to benefit them }\end{array}$ & 7.4 & 22.2 & 11.1 & 25.9 & 33.3 & 3.56 & 1.36 \\
$\quad$ Average & & & & & & $\mathbf{3 . 7 0}$ & $\mathbf{1 . 2 8}$ \\
\hline
\end{tabular}

$\mathrm{SD}=$ Strongly Disagree $\mathrm{D}=$ Disagree $\mathrm{N}=$ Neutral $\mathrm{A}=$ Agree $\mathrm{SA}=$ Strongly Agree

The bivariate linear regression model linking System Surveillance and tax fraud is presented in below. The linear regression analysis shows that there is a positive relationship, $R=0.464$ and $R^{2}=0.215$ which means that approximately $21.5 \%$ of the resultant changes in tax fraud among large taxpayers as indicated by a unit variation in System Surveillance. 
Table 12. Model Summary for Corruption

\begin{tabular}{ccccc}
\hline Model & R & R Square & Adjusted R Square & Std. Error of the Estimate \\
\hline 1 & .358 & 0.129 & 0.112 & 0.3897 \\
\hline
\end{tabular}

a Predictors: (Constant), Corruption

The bivariate linear model significance for corruption and fraud risk was determined using ANOVA. Regression results revealed that the linear relationship between corruption and fraud risk has an $F$ value of $\mathrm{F}=7.668$ which is significant with $\mathrm{p}$ value $\mathrm{p}=.008<\mathrm{p}=.05$ implicating that the overall model is significant in predicting the effect of corruption on the performance of state corporations in Mombasa county.

Table 13. Analysis of Variance for Corruption

\begin{tabular}{clccccc}
\hline Model & & Sum of Squares & Df & Mean Square & F & Sig. \\
\hline 1 & Regression & 1.165 & 1 & 1.165 & 7.668 & .008 \\
& Residual & 7.897 & 52 & 0.152 & & \\
& Total & 9.061 & 53 & & & \\
\hline
\end{tabular}

a Dependent Variable: Fraud Risk

b Predictors: (Constant), Corruption

The regression coefficients for the model revealed that the beta coefficient of the resulting regression model, the constant $\beta_{0}=3.727$ is significant with $p$ value $p=0.000<p=0.05$. The coefficient $\beta=$ 0.177 , has a $p$ value, $p=0.000$ which is less than $p=0.05$. This implies that the regression model linking corruption and fraud risk is significant. The findings agree with the findings of a study by Maxwell et al (2012) which revealed that accurate targeting of those who need assistance poses significant corruption risk. The study findings are consistent with the findings of a study by Graycar et al. (2012) which concluded that deficiency in control structure positively and significantly influences the existing opportunities for corruption thereby developing systematic methods. Thanos and Petrou (2014) in concurrence, attest that corruption acts as a "helping hand" to commerce. Evidence from bank records show that bribing mechanisms had helped facilitate transactions and enable private agents to pursue economic activities they could not pursue otherwise.

Table 14. Regression Coefficients for Corruption

\begin{tabular}{ccccccc}
\hline Model & Coefficients & B & Std. Error & Beta & t & Sig. \\
\hline 1 & (Constant) & 3.727 & 0.242 & & 15.378 & 0.000 \\
& Corruption & 0.177 & 0.064 & 0.358 & 2.769 & 0.008 \\
\hline
\end{tabular}

a Dependent Variable: Fraud Risk

\section{Combined Effect of Drivers of Fraud Risk on Fraud Risk}

The study used a multivariate regression model to so as to establish the drivers of fraud risk among state corporations in Mombasa County in Kenya. The overall regression model of the study was $Y=\beta_{0}+\beta_{1}$ $X_{1}+\beta_{2} X_{2}+\varepsilon$ Where; $Y=$ Fraud Risk, $X_{1}=$ Financial Misstatement, $X_{2}=$ Corruption and $\varepsilon=$ Error term. The model summary results for the study variables indicated that Financial Misstatement and Corruption account for $51.2 \%$ of the variation in fraud risk among state corporations in Mombasa County. This is indicated by an $\mathrm{R}$-square value of 0.512 . The regression results show that $\mathrm{R}$ was 0.715 which means that the relationship between the independent variables and the dependent variable is positive.

Table 15. Model Summary for the Study Variables

\begin{tabular}{ccccc}
\hline Model & R & R Square & Adjusted R Square & Std. Error of the Estimate \\
\hline 1 & .715 & 0.512 & 0.482 & 0.2975 \\
\hline
\end{tabular}

a Predictors: (Constant), Corruption, Financial Misstatement, Asset misappropriation 
The results of the analysis of variance for the study variables showed that the overall regression model linking Financial Misstatement, Corruption and their effect on fraud risk among state corporations in Mombasa County was significant as indicated by $F(3,50)$ statistic which was less than 0.05 at $5 \%$ level of significance. $\mathrm{F}$ calculated is 17.467 while $\mathrm{f}$ critical is 2.79 . $\mathrm{F}$ calculated is greater than the $\mathrm{F}$ critical (17.467 $>2.79$ ), this showed that the overall model was statistically significant at $5 \%$ significance level. The results of the study are as shown in table 16.

Table 16. ANOVA for the Study Variables

\begin{tabular}{clccccc}
\hline Model & & Sum of Squares & Df & Mean Square & F & Sig. \\
\hline \multirow{2}{*}{1} & Regression & 4.637 & 3 & 1.546 & 17.467 & .000 \\
& Residual & 4.424 & 50 & 0.088 & & \\
& Total & 9.061 & 53 & & & \\
\hline
\end{tabular}

a Dependent Variable: Fraud Risk

b Predictors: (Constant), Corruption, Financial Misstatement, Asset misappropriation

To determine the association linking the dependent variables and the dependent variable, regression coefficients were produced as shown in table 17 below.

Table 17. Regression coefficients for the Study Variables

\begin{tabular}{|c|c|c|c|c|c|c|}
\hline Model & Coefficients & B & Std. Error & Beta & $t$ & Sig. \\
\hline \multirow[t]{3}{*}{1} & (Constant) & 1.446 & 0.411 & & 3.522 & 0.001 \\
\hline & Financial Misstatement & 0.379 & 0.08 & 0.469 & 4.733 & 0.000 \\
\hline & Corruption & 0.177 & 0.049 & 0.358 & 3.613 & 0.001 \\
\hline
\end{tabular}

a Dependent Variable: Fraud Risk

Therefore, optimal multivariate Regression Model for the study is as shown below:

Fraud Risk $=1.446+0.379$ Financial Misstatement +0.177 Corruption

Regression coefficients for the study variables showed that financial misstatement had a positive and significant effect among state corporations in Mombasa County $(\beta=0.379$, Sig $=0.000)$. This implies that an increase in the cases of manipulation of financial records, improper disclosure of financial statement information in the organization, cases of overstating of expenditure while providing accountability reports, organizational policy on how to handle financial statements, Forensic accounting and auditing leads to 0.379 unit effect on fraud risk among state corporations in Mombasa County. The findings agree with the findings of a study by Odhiambo (2013) which found out that financial fraud loss and liquidity ratios had a strong and significant influence on financial performance of commercial banks in Kenya. Similarly, Makori (2016) showed that internal control systems influence fraud risk management; positively and significantly. Akindele (2011) in concurrence advised that adequate internal control mechanism be put in place and that workers satisfaction and comfort be taken care of. Moreover, Abiola and Oyewole (2013) in agreement showed a statistically significant positive relationship between risk assessment and fraud detection. Similarly, Akinyomi (2010) in a study on the effect of financial statements on Nigerian banks found that there was a strong positive relationship between risk assessment and fraud management while studying fraud in Nigerian banks. Moreover, the findings of the study also showed that corruption had a positive and significant influence among state corporations in Mombasa County $(\beta=0.177, \operatorname{Sig}=0.001)$. This implies that cases of bribery of employees by management to benefit them, presence of policies to regulate cases of payoffs and kickbacks, presence of heavy penalties levied against perpetrators of payoffs and kickbacks and presence of cases of bribery of employees by management to benefit them leads to 0.177 unit effect on fraud risk among state corporations in Mombasa County. The findings agree with the findings of a study by Maxwell et al (2012) which revealed that accurate targeting of those who need assistance poses significant corruption risk. The study findings are consistent with the findings of a study by Graycar et al (2012) which concluded that deficiency in control structure positively and significantly influences the existing opportunities for corruption thereby developing systematic methods. Thanos and Petrou (2014) in concurrence, attest that corruption acts as a "helping hand" to commerce. Evidence from bank records 
show that bribing mechanisms had helped facilitate transactions and enable private agents to pursue economic activities they could not pursue otherwise.

\section{Conclusions}

The study concluded that the effect of financial misstatement as a driver of fraud risk among state corporations in Mombasa County was positive and significant. The study concluded that an increase in financial misstatement activities for instance cases of manipulation of financial records, improper disclosure of financial statement information in the organization, cases of overstating of expenditure while providing accountability reports, organizational policy on how to handle financial statements and Forensic accounting and auditing has a positive and significant effect on fraud risk among state corporations in Mombasa County. The study also concluded that the effect of corruption on fraud risk among state corporations in Mombasa County was positive and significant. The study concluded that an increase in corrupt activities for instance cases of bribery of employees by management to benefit them, presence of policies to regulate cases of payoffs and kickbacks, presence of heavy penalties levied against perpetrators of payoffs and kickbacks and presence of cases of bribery of employees by management to benefit them positively and significantly affect fraud risk among state corporations in Mombasa County.

\section{Recommendations}

To reduce financial misstatement reporting, the study recommends the management of state corporations in Mombasa County to adopt more robust monitoring measures to avoid manipulation of their financial records. There is also need for the management of state corporations to emphasize on proper disclosure of financial statement information. The study also recommends the management of state corporations to ensure that their expenditures are not overstated through the provision of accountability reports. The study further recommends for the adoption of policies to handle financial statements such as Forensic accounting and auditing. The study recommends the management of state corporations in Mombasa County to put in place policies to regulate cases of payoffs and kickbacks. There is also need for the state corporation's management to adopt severe and punitive penalties measures against perpetrators of payoffs and kickbacks. There is also need for state corporations' management to enhance their employee's remuneration so as to discourage them from taking bribes.

\section{Future researches}

Since this study only focused on state corporations in Mombasa County, the study recommends other researchers and scholars to investigate more on state corporations in other counties to determine factors that predispose them to fraud risk. Moreover, the study recommends prospective researchers to look into fraud risk factors affecting state corporations in other counties in addition to corruption and financial misstatement.

\section{Acknowledgement}

I am grateful to all those who contributed significantly to the development of this thesis. I also wish to convey my sincere gratitude and appreciation to my supervisors; Dr. David N. Kiragu (PhD) and Dr. Kamau Riro (PhD) who spent countless hours guiding me throughout the development and accomplishment of this work. I am deeply indebted to them for their unwavering support, patience and encouragement shown throughout their supervision.

\section{References}

1. Abiola, J. (2013). The Impact of ICT on Internal Control's Effectiveness in Prevention and detection of Fraud. Available: http://www.dora.dmu.ac.uk.

2. Akindele, R. I. (2011). Fraud as a negative catalyst in the Nigerian banking industry. Journal of Emerging Trends in Economics and Management Sciences, 2(5), 357-363. 
3. Akinyomi. O. J (2010). The effect of internal control systems on Nigerian banks. International journal of accounting, 2 (1).

4. Association of Certified Fraud Examiners (ACFE) (2014) Global Fraud Study. Report to the Nations on Occupational Fraud and Abuse.

5. Chiezey, U., \& Onu, A. J. C. (2013). Impact of fraud and fraudulent practices on the performance of banks in Nigeria. British Journal of Arts and Social Sciences, 15(1), 12-25.

6. Cooper, D.R., \& Schindler, P.S. (2011). Business Research Methods (11 ${ }^{\text {th }}$ ed.). New Delhi-India. McGraw-Hill Publishing, Co. Ltd.

7. Cressey, D. (2012). Other People's Money: A study in the Social Psychology of Embezzlement, New Jersey, Patterson Smith Publishing Corporation

8. Cronbach, L.J. (1951).Coefficient Alpha and the Internal Structure of Tests. Psychometrika, 16297334. Doi: $10.1007 /$ BF02310555.

9. Garg, G., \& Kothari, C. R. (2014). Research Methodology. Methods and Techniques. New Age International Publishers. New Delhi-110002.

10.Gikiri, M. M. (2012). Effects of attitude, norms, and perceived behavior control on intentions to become a teen father (Doctoral dissertation, Capella University).

11. Hooper T. (2016). The Fight against Fraud", Internal Auditor, Vol. 62 No. 1, pp. 62-6.

12.Kwame N., G.O, (2014) Bank management principles and practice. Lagos Malthouse press Ltd, Lagos Nigeria.

13.Makori, R. G. (2016). Influence of internal control systems on fraud risk management among commercial banks in Kisii town, Kenya (Doctoral dissertation, School of Business and Economics).

14.Nunnally, J. C. (1978). Psychometric Theory. New York: Mcgraw-Hill.

15.Odhiambo (2013) Evaluation of Fraud Management Strategies Adopted By Insurance Companies in Kenya.

16.PPDA (2008). Report on Compliance Checks undertaken on 120 Procuring and Disposing Entities.

17.Price water house Coopers, (2015). The report on the Statistics and Trend of Frauds for the year 2015, Central bank of Kenya.

18. Rae and Subramane (2008). Bank Frauds in India: Emerging Challenges, Journal of Commerce.

19.Rubin H. (2015). Fraud as a Negative Catalyst in the Nigerian banking industry. Journal of Emerging Trends in Economics and management Sciences (JETEMS).

20.Serekan (2013) Research Methodology and Techniques, 2nd Ed. New Delhi, Age Publishers.

21.Soltani H. (2013) Accounting and Financial Analysis in the Hospitality Industry. ButterworthHeinemann. India.

22.Upagade, V., \& Shende, A. (2012). Research methodology. S. Chand\& Company Ltd. New Delhi,

23.Zahra, S. A., Priem, R. L., and Rasheed, A. A. (2007), Understanding the Causes and Effects of Top Management fraud', Organizational Dynamics, 36 (2), 122-139. 